\title{
SPORY O MLYN GÓRNY W BIEŃCZYCACH W LATACH 1792-1838
}

STRESZCZENIE: Podkrakowska wieś Bieńczyce stanowiła część uposażenia proboszcza parafii pw. św. Floriana na Kleparzu, stanowiąc przy tym główne źródło jego dochodu. W XVIII i XIX w. rozegrał się w niej konflikt pomiędzy młynarzami a gromadą i ks. Antonim Krząnowskim, a po jego śmierci z ks. Franciszkiem Kolendowiczem. Kolejno następujący po sobie trzej młynarze z Młyna Górnego zaniedbywali obowiązki, wskutek czego stan młyna ulegał systematycznemu pogorszeniu. Artykuł podejmuje problematykę przyczyn, przebiegu oraz skutków toczonych w latach 1792-1838 sporów o młyn.

SŁOWA KLUCZOWE: Antoni Krząnowski, Bieńczyce, Franciszek Kolendowicz, Hugo Kołłątaj, konflikt, Młyn Górny.

\section{DISPUTES OVER THE UPPER MILL IN BIEŃCZYCE IN THE YEARS 1792-1838}

\begin{abstract}
Bieńczyce, a village near Kraków, was a benefice of a parson of St Florian's parish in Kleparz, providing his main source of income. In the $18^{\text {th }}$ and $19^{\text {th }}$ century the countryside witnessed a conflict between millers and peasants as well as a Rev. Antoni Krząnowski, and after his death Rev. Franciszek Kolendowicz. Three successive millers from the Upper Mill neglected their duties, which caused a gradual deterioration of the mill's condition. The article focuses on the causes, course and results of conflicts over the mill in the years 1792-1838.
\end{abstract}

KEYWORDS: Antoni Krząnowski, Bieńczyce, conflict, Franciszek Kolendowicz, Hugo Kołłątaj, Upper Mill. 


\section{Wstęp}

Młyn obok kościoła, szkoły i dworu, zaliczyć można do najważniejszych zabudowań w każdej wsi. Bieńczyce, obecnie dzielnica Krakowa, a niegdyś wieś oddalona od miasta o 6 mil, nie posiadały własnego kościoła, administracyjnie więc należały do parafii w Raciborowicach ${ }^{1}$. Pomimo tego, miejscowość ta odgrywała w strukturze kościelnej niezwykle ważną rolę, stanowiła bowiem częśćc uposażenia i główne źródło dochodu prepozyta kapituły przy kolegiacie pw. św. Floriana w Krakowie już od XIV wieku². W okresie od XVIII do początku XX w. wypracowano niezwykle obszerną dokumentację archiwalną związaną $\mathrm{z}$ daninami pobieranymi ze wsi, chłopami ją zamieszkującymi, a także dotyczącą prac remontowych i budowlanych w niej prowadzonych.

W latach 1792-1838 Bieńczyce stały się miejscem sporu pomiędzy proboszczem parafii pw. św. Floriana i gromadą bieńczycką a nieposłusznymi młynarzami. Zażegnanie tego pozornie błahego konfliktu zajęło 46 lat, co przyczyniło się do zgromadzenia w archiwum parafialnym licznych źródeł dokumentujących jego przebieg.

\section{Bieńczyce w latach poprzedzających spór o młyn (1778-1792)}

Ks. Hugo Kołłątaj poczynając od 1775 r., kiedy to mianowany został kanonikiem kapituły katedralnej, podejmował starania o pozyskanie beneficjów ${ }^{3}$. Jak zauważa Bolesław Limanowski, nieprzychylni Kołłątajowi ludzie chętnie obwiniali go o chciwe gromadzenie mająt$\mathrm{ku}$, a także nadużywanie swojej władzy ${ }^{4}$. Wśród dóbr przezeń pozyskanych znalazły się również Bieńczyce, które w $1778 \mathrm{r}$. wydzierżawił od ówczesnego proboszcza parafii pw. św. Floriana w Krakowie, ks. Antoniego Krząnowskiego ${ }^{5}$. Początkowo sporządzono umowę na okres trzech

\footnotetext{
${ }^{1}$ Archiwum parafii pw. św. Floriana w Krakowie (dalej: APFK), sygn. 71, Visitatio Ecclesiae Collegiatae Sancti Floriani Clepardiae sitae 1711, k. 4r, rps.

2 Tamże; J. Długosz, Liber beneficiorum Dioecesis Cracoviensis, t. 1, wyd. A. Pr z éz d z i e c k i, Kraków 1863, s. 479.

${ }^{3}$ J. K u ś, Kottataj i Kapituła Krakowska, „Rocznik Krakowski” 1977, t. 48, s. 21-24.

${ }^{4}$ B. L i m a n o w s k i, Hugo Kotłataj, Warszawa [1920], s. 19-20.

${ }^{5}$ Zarówno opracowania jak i źródła podają różne daty roczne śmierci ks. Antoniego Krząnowskiego. Według katalogu duchowieństwa parafii pw. św. Floriana ks. Jana Szczepaniaka, a także według epitafium znajdującego się w nawie bocznej kościoła pw. św.
} 
lat, jednak po dwóch latach jej trwania Kołłątaj otrzymać miał ustną obietnicę przedłużenia dzierżawy ${ }^{6}$. Ta jednakże została przez ks. Krząnowskiego wycofana ${ }^{7}$.

Przychylny Kołłątajowi Jan Śniadecki w swoim opisie sporu twierdził, że ks. Krząnowski ,[...] namówiony od prałatów krakowskich wydał potajemnie kontrakt jednemu prawnikowi, który zjechawszy do Bieńczyc na objęcie posiadłości napadł na ludzi i nie wiedzącego o niczym w Krakowie Kołłątaja i dał zaczepkę do popełnionego boju i gwałtu"§. Zgoła odmienna była narracja prowadzona przez drugą stronę sporu: „W 1779 r., a więc rok przed reformą uniwersytetu, ks. Kołłątaj różnemi obietnicami skłonił ks. A. Krząnowskiego, [...] że mu wypuścił w dzierżawę wieś Bieńczyce. Podawszy projekt ugody [...] podsunął [kontrakt] ks. Krząnowskiemu do podpisu, który nieczytając $\mathrm{w}$ dobrej wierze podpisał. Tymczasem zaczął ks. Kołłątaj gospodarować w Bieńczycach bardzo niekorzystnie: powycinał sady, a zasadził kwiatami, [...] płoty i słomę palił, browar i domek służby folwarcznej dla pięknego widoku przeniósł na inne miejsce $[\ldots], \mathrm{w}$ dworze porobił samowładne zmiany, poddanych wysyłał o mil 15 do młocki dziesięcin, łąki poorał, groble u stawów rozrzucił, tudzież warunków kontraktu nie dotrzymał"9. Jako źródło takiego przedstawienia sprawy autor wskazał parafialne archiwum, jednakże w żadnym z fascykułów objętych kwerendą nie udało się odnaleźć wzmianek o rzeczonym konflikcie ${ }^{10}$.

Kolejne lata po zakończonej dzierżawie wsi przez ks. Kołłątaja nie przyniosły jednakże spokoju. W 1791 r. doszło do buntu chłopów prze-

Floriana w Krakowie, miała ona miejsce w 1798 r., podczas gdy rękopiśmienne dokumenty dotyczące regulacji spraw majątkowych po śmierci ks. Krząnowskiego wskazują na rok 1795. J. S z c z e p a n i a k, Duchowieństwo świętofloriańskie w XVIII i XIX wieku, [w:] Studia z dziejów kościoła św. Floriana w Krakowie, red. Z. K 1 i ś, Kraków 2007, s. 69-70; APFK, sygn. 36, Obrachunek między exekutorami po x. Antonim Krząnowskim a WJP Kałużyńskim, k. 1r, rps.

${ }^{6}$ J. K u ś, dz. cyt., s. 27.

7 Tamże.

8 J. Ś n i a d e c ki, Żywot literacki Hugona Kołlątaja z opisaniem stanu Akademii Krakowskiej w jakim się znajdowała przed rokiem 1780, wyd. H. Barycz, Wrocław 1951, s. 49-50.

${ }^{9}$ Pamiatka 700 letniej rocznicy założenia kościoła i kolegiaty św. Floryana przy Krakowie na Kleparzu, Poznań 1883, s. 10-11.

10 Tamże. 
ciwko zwiększeniu wymiaru pańszczyzny z 3 do 5 dni w tygodniu, wskutek czego 10 stycznia 1792 r. wystosowano do ks. Krząnowskiego obszerną listę żądań ${ }^{11}$. Oczekiwano m.in., że każda sobota będzie dniem wolnym od pracy $^{12}$, podwozy zredukowane zostaną do $6 \mathrm{mil}^{13}$, czyli ówczesnej odległości między Bieńczycami a Krakowem, areał pola, które każdy z kmieciów miał zaorać na wiosnę i zimę ustalony zostanie na 40 zagonów $^{14}$, przywrócona być miała również instytucja stróża nocnego od godziny przed zachodem słońca do dwóch godzin po wschodzie w miejsce nowo ustanowionej straży całodziennej ${ }^{15}$. Na te żądania 18 stycznia 1792 r. udzielona została przez proboszcza pisemna odpowiedź, w której przychylił się on do roszczeń zagrodników, o ile zgodne były z treścią inwentarza probostwa z 1706 roku $^{16}$. Zastrzegł przy tym, że kompromis ten obowiązywać ma wyłącznie do wiosny 1793 roku $^{17}$. W tym samym dokumencie ks. Krząnowski wskazał, że w 1772 roku grunty użytkowane przez chłopów zostały pomierzone. W przypadku wielu zagrodników okazało się, że użytkowana przez nich powierzchnia pól jest większa, niż wynikało to z zawartych kontraktów. Wobec tego chłopi sami zwrócić się mieli do proboszcza z propozycją, że wolą odpracowywanie dodatkowego dnia pańszczyzny niż zmniejszenie wielkości użytkowanych przez nich gruntów. Wobec złożonych w 1792 r. skarg względem wymiaru pańszczyzny, grunty te decyzją ks. Krząnowskiego miały jednakże zostać zmniejszone ${ }^{18}$.

Sam proboszcz sporządził ponadto nieopatrzoną datą obszerną notatkę, w której opisał przebieg buntu gromady. Zapisał, że starał się przede wszystkim, „,[...] ażeby nie tylko w boiazni Boskiey, zgodzie,

\footnotetext{
11 APFK, sygn. 7, Dekret Gromady w Akta Sądow Rektorskich Szkoły Głowney Koronney wpisany 16 V 1792, k. 1r, rps.

12 Dzień ten uprzednio pozostawał do wolnej dyspozycji chłopów, stąd też wykorzystywali go do pracy na dzierżawionym przez nich gruncie. Pozostałe dni tygodnia przeznaczone były na pracę na rzecz dworu. APFK, sygn. 80, Regestr żądań Gromady Bienczyckiey z Rezolucyami, k. 1r, rps.

${ }^{13} \mathrm{~W}$ piśmie tym wykazywano, że przed podjęciem reform podróżowano co najwyżej o 3 mile, zaś w wyniku reform odległość miała być zwiększona do 10 mil. Zgodnie z inwentarzem sporządzonym w 1706 r. odległość ta miała wynosić 6 mil. Tamże.

14 Tamże.

15 Tamże, k. 1v.

${ }^{16}$ Inwentarza tego nie udało się odnaleźć.

17 APFK, sygn. 63, Odpowiedz Gromadzie, passim, rps.

18 Tamże.
} 
pokoiu y zabezpieczeniu [gromada] profitowała, ale żeby iey iak z Dozorców, tak też Dzierzawcow żaden krzywdy y ciężkości nie czynił, Panszczyzny nie podnosił, dawnych zwyczaiow nie odmieniał, a przeto żeby doskonałą charmonię [sic!] między Dworem y nią mocno utrzymywał [...]"19. W 1791 roku dotrzeć miała doń niespodziewana informacja o buncie gromady. Dopiero wraz z przybyciem reprezentantów i przedstawieniem żądań dowiedzieć się miał, że dzierżawiący wieś w owym czasie Antoni Chojnacki zwiększył wymiar pańszczyzny oraz innych danin ${ }^{20}$. Ks. Krząnowski nakazać miał sporządzenie „,regestru uciążliwości”, a następnie przywrócił pańszczyznę i inne daniny do stanu zgodnego z inwentarzem z 1706 roku $^{21}$. Gromada jednakże ,[...] na zdradę y oczywistą X. Proboszcza zniewa[gę] [...] z pomiędzy siebie Klemensa Zyburę Chałupnik[a] do Warszawy z memoriałem kłamliwych zaskarzen pełnym wyprawiła [...]",22. Przytoczona skarga Zybury odnosiła się do wysokości pańszczyzny oraz pobieranego czynszu. Do rozpoznania tej sprawy skierowany został jako sędzia delegowany ks. Bonifacy Garycki, proboszcz kolegiaty pw. św. Anny w Krakowie. W wydanym przez siebie wyroku uznał rację proboszcza świętofloriańskiego, oddalając przy tym wszystkie przedłożone zażalenia ${ }^{23}$.

Spór rozstrzygnięty został jeszcze w 1792 roku na mocy dekretu wydanego 16 maja przez Sąd Rektorski Szkoły Głównej Koronnej, który nie uznał skarg i zażaleń gromady, zwracając uwagę na to, że nie tylko ks. Krząnowski nie przymnażał pracy chłopom bieńczyckim, ale i ,nie mało [im] ulżył"24.

19 APFK, sygn. 63, Uwiadomienie o zbuntowaney Gromadzie w Bieńczycach w Roku 1791 z strony WJX Krząnowskiego Koscioła S. Floryana Proboszcza uczynione, k. 1r, rps.

${ }^{20}$ Tamże.

21 Tamże.

22 Tamże, k. 1v.

23 Archiwum Uniwersytetu Jagiellońskiego w Krakowie (dalej: AUJ), sygn. 1/27, Dekret Sądu Delegacyjnego Szkoły Głowney Koronney z dn. 14 III 1792 r., passim, rps.

24 APFK, sygn. 7, Dekret Gromady w Akta Sądow Rektorskich Szkoły Głowney Koronney wpisany 16 V 1792, k. 7r, rps.; Archiwum Narodowe w Krakowie (dalej: ANK), Wolne Miasto Kraków (29/200), sygn. WMK IX-26, Odpis Dekretu Sądu Szkoły Główney Koronney z 1792 r., k. 7r, rps. 


\section{Młyn Górny w Bieńczycach w latach poprzedzających spór}

Na przestrzeni stuleci w Bieńczycach istniały jednocześnie dwa mły$n y^{25}$. Pierwszą wzmianką dokumentującą taki stan rzeczy jest piętnastowieczne Liber beneficiorum ks. Jana Długosza ${ }^{26}$, jednakże dopiero w źródłach osiemnastowiecznych zaczęto je rozróżniać nazywając odpowiednio młynami ,górnym” i „dolnym”. Nie stanowiły one własności mieszkających w nich młynarzy, lecz dzierżawione były na podstawie przywileju przez każdoczesnego prepozyta kapituły św. Floriana oraz na mocy zawieranego kontraktu ${ }^{27}$.

Spośród obu młynów za bardziej intratny uchodził Młyn Górny. Główną tego przyczyną było jego usytuowanie w pobliżu zabudowań dworskich. Już w opisie zawartym w Liber beneficiorum Długosza odnotowano, że pobierano z niego 9 marek czynszu, podczas gdy z Młyna Dolnego ściągano tylko 7 marek $^{28}$. Stan ten utrzymał się również w kolejnych latach, co potwierdza inwentarz z 1639 roku $^{29}$. Na początku XVIII w. z niewiadomych przyczyn czynsz został zrównany i wynosił po 200 tynfów $^{30}$, już jednak w kolejnych latach ponownie uległ zmianie, tak iż w 1792 r., bezpośrednio poprzedzającym konflikt będący przedmiotem niniejszego opracowania, pobierano 270 złp czynszu z Młyna Górnego i 150 złp z Młyna Dolnego. Dysproporcja ta

${ }^{25} \mathrm{H}$. K r a m a r z, Mtynarze i mlynarstwo zbożowe w Galicji (Z problematyki uprzemystawiania rzemiosta chtopskiego), [w:] Polska i Polacy w XIX-XX wieku. Studia ofiarowane Profesorowi Mariuszowi Kulczykowskiemu w 70. Rocznice Jego urodzin, red. K. Ś 1 u s a r c z y k, Kraków 2002, s. 296-302; M. D e m b i ń s k a, Przetwórstwo zbożowe w Polsce średniowiecznej (X-XIV wiek), Wrocław 1973, s. 77-89.

${ }^{26}$,Item praedicta villa habuit duo molendina in flumine Dlubnya, quorum unum datum in haereditatem perpetuam solvit praepositurae pro annuo censu septem marcas, octo capones, unum octuale cervisiae, aliud solvit novem marcas et novem capones". J. D ł u g o s z, dz. cyt., s. 479.

${ }^{27}$ Z. P odwińska, Rozmieszczenie wodnych mlynów zbożowych w Małopolsce w XV wieku, „Kwartalnik Historii Kultury Materialnej” 1971, nr 1, s. 373-402.

${ }^{28}$ Tamże.

${ }^{29}$ Opis wsi Bieńczyce przytoczony w tym źródle jest tożsamy z opisem zawartym w Liber beneficiorum ks. Jana Długosza. AUJ, sygn. 172, Regestrum Ecclesiae Collegiatae s. Floriani, s. 2, rps.

${ }^{30}$ APFK, sygn. 7, Inwentarz Robocizn, Podatków, Danin, Poddanych Wsi Bińczyc do Prowentu teyże Wsi należących w Roku Tysięcznym Siedemsetnym Szóstym skonnotowany, k. 1v, rps. 
utrzymywała się także w kolejnych latach - w 1804 r. z Młyna Górnego pobierano $67 \mathrm{fl}$ czynszu, a z Młyna Dolnego 37,30 $\mathrm{fl}^{31}$.

Pierwsza wzmianka o osiemnastowiecznych młynarzach pracujących w Bieńczycach pochodzi z Inwentarza robocizn... z 1706 roku. Dokument ten wskazuje, że w owym czasie w Młynie Górnym pracował Stanisław Sasko, a w Dolnym nieznany $\mathrm{z}$ nazwiska Wawrzyniec ${ }^{32}$. Obaj zobligowani byli do mielenia w pierwszej kolejności wszystkich zbóż dla dworu bieńczyckiego, dbania o budynki dworskie, a także pełnienia ,powinności inszych" względem gromady bieńczyckiej ${ }^{33}$. W 1714 r. ówczesny prepozyt kapituły pw. św. Floriana, ks. Andrzej Augustyn Czyrzyckiewicz, na mocy przywileju nadał Młyn Górny na „troie dożywocia” chłopowi bieńczyckiemu, Wojciechowi Czernikowskiemu oraz jego żonie Dorocie, synowi i córce ${ }^{34}$. Po jego śmierci rzeczony młyn przeszedł w ręce tegoż syna, Tomasza Czernikowskiego, oraz jego żony Reginy ${ }^{35}$. Z ich małżeństwa na świat przyszło dwóch synów: Tomasz oraz Piotr ${ }^{36}$. Po śmierci męża, wdowa Regina Czernikowska wyszła ponownie za mąż. Z Szymonem Okoniem miała trzeciego syna - Stanisława ${ }^{37}$. Jak poświadczają zachowane źródła, Szymon Okoń korzystał z gospodarstwa, nie uczestnicząc przy tym w kosztach jego utrzymania ${ }^{38}$. Roszczenia do młyna po zmarłym Tomaszu Czernikowskim wysunęli jego syn również Tomasz i Stanisław, zrezygnował z nich natomiast wspomniany wyżej Piotr ${ }^{39}$. Dodać ponadto należy, że rodzina Okoniów domagała się od ks. Krząnowskiego uznania części majątku za wniesioną przez Szymona, jednakże wobec nieprzedstawienia dowodów została ona uznana za spuściznę po Wojciechu i Dorocie

\footnotetext{
31 APFK, sygn. 79, Inwentarz Probostwa Sgo Floryana na Kleparzy w Krakowie w Cyrkule y Diecezyi tegoż Naziwska w maju 1804 sporządzony, rps.

32 APFK, sygn. 7, Inwentarz Robocizn, Podatków, Danin, Poddanych Wsi Bińczyc do Prowentu teyże Wsi nalezących w Roku Tysięcznym Siedemsetnym Szóstym skonnotowany, k. 1v, rps.

33 Tamże.

${ }^{34}$ Biblioteka Jagiellońska w Krakowie, sygn. rkp. dypl. 330, Kontrakt na Młyn Górny, passim, rps.

${ }^{35}$ APFK, sygn. 6, Dekret z dnia 14 marca 1792, k. 1r-2v, rps.

36 Tamże.

37 Tamże.

${ }^{38}$ Tamże, k. 3r-3v.

39 Tamże.
} 
Czernikowskich $^{40}$. Na mocy przywileju z 1770 r. Młyn Górny przeszedł więc w ręce Tomasza Czernikowskiego ${ }^{41}$.

W czasie zarządzania przezeń młynem zaciągnięte zostały liczne pożyczki. Oprócz 432 złp pozostających do spłaty po uprzednich młynarzach, testament Tomasza Czernikowskiego (syna) wzmiankował również dług 21 złp zaciągnięty u niego przez Stanisława Okonia na zakup „pięciu garcy gorzałki” ${ }^{42}$. Oprócz tych sum, do spłaty pozostawało jeszcze $970 \mathrm{złp} \mathrm{z} \mathrm{tytułu} \mathrm{prowadzonych} \mathrm{napraw}{ }^{43}$.

Po śmierci Tomasza Czernikowskiego (syna), jego brat Piotr ponownie zrezygnował z objęcia młyna. W związku z tym ks. Krząnowski podjął starania o sprowadzenie do Bieńczyc chłopa z Kantorowic Tomasza Bochenka ${ }^{44}$. Wybór ten był z pewnością nieprzypadkowy, gdyż córka rzeczonego Bochenka, Apollonia, była żoną zmarłego Tomasza Czernikowskiego (syna) ${ }^{45}$. W 1784 r. sporządzono szczegółowy kontrakt regulujący warunki objęcia przezeń młyna. W dokumencie tym wyliczono m.in., że przejmie on długi pozostałe po poprzednikach ${ }^{46}$. Niejasnym pozostaje, czy rzeczywiście objął młyn w posiadanie. Liczne źródła wspominają bowiem o jego rezygnacji na rzecz Macieja Ziomka, drugiego męża Apollonii. Fakt, iż kontrakt z Bochenkiem negocjowano w 1784 r., a z Ziomkiem spisano go dopiero $\mathrm{w} 1788 \mathrm{r}$. daje jednakże mocną podstawę do przypuszczeń, jakoby Bochenek pełnił funkcję młynarza przynajmniej przez krótki czas $^{47}$. Po przejęciu młyna Ziomkowie zapłacili 1003 złote na rzecz uregulowania ciążącego na młynie zadłużenia, pociągnęli również Stanisława Okonia do zwrotu pieniędzy za alkohol ${ }^{48}$.

\footnotetext{
40 Tamże.

41 Tamże.

42 Testament ten nie zachował się w archiwum parafialnym. Zachowała się o nim jedynie pośrednia wzmianka. Tamże.

43 Tamże.

${ }^{44}$ Tamże, k. 1r-2v.

45 Tamże.

46 APFK, sygn. 6, Punkta do przywileiu na Młyn Górny w Bieńczycach po śmierci Tomasza Czernikowskiego [...] w roku 17845 maia [...] Bochenkowi do uwiadomienia podane, passim, rps.

47 APFK, sygn. 28, Kontrakt na Młyn Górny Ziomkom dany 178820 października, passim, rps.

${ }^{48}$ APFK, sygn. 6, Dekret z dnia 14 marca 1792, k. 3v, rps.
} 


\section{Spór o Młyn Górny między Maciejem Ziomkiem a gromadą bieńczycką i proboszczami świętofloriańskimi (1792-1801)}

W latach 1795-1800 na młynarza Macieja Ziomka wpłynęło do ks. Antoniego Krząnowskiego kilkadziesiąt skarg wystosowanych zarówno przed dwór, jak i chłopów. Pierwsze obszerne ,punkta na Macieja Ziomka” spisane zostały w 1796 r. $^{49}$, sporządzono wówczas również szczegółowy inwentarz młyna ${ }^{50}$. Wśród wyliczonych przewinień wskazano, że młynarz nie reperował zabudowań, a gdy zostali do tego skierowani pracownicy, on ich ,[...] bałamucił, chociaż sam się na tym nie znał"51. Także w świadectwie danym przez ówczesnego wójta bieńczyckiego wskazano, że Ziomek wezwany przez proboszcza do złożenia sprawozdania, zapytany został przezeń, czy przeprowadzi naprawę młyna, na co odpowiedział, że „Nie będzie [tego czynił], bo temu nie potrafi" ${ }^{52}$. Reparację izbicy ${ }^{53}$, jazu ${ }^{54}$ i podjazia przeprowadzono zatem kosztem 2076 złp, pokrytym w całości przez ks. Krząnowskiego $^{55}$, chociaż sam młynarz w naprawie nie uczestniczył, a jedynie udostępnił ,[...] parę bani i sanki z dwoygiem ludzi na ieden dzień"56.

Przyczyny konieczności przeprowadzenia prac remontowych przy młynie bieńczyckim udokumentowane zostały bardzo szczegółowo, gdyż w związku ze skargami na Ziomka w lipcu 1796 r., a więc tuż przed naprawą, przeprowadzono rewizję, z której sporządzono obszerne sprawozdanie. Wśród najbardziej zniszczonych elementów wyliczono zdezelowanie w całości młynicy oraz przegnicie jej drewnianych elementów.

\footnotetext{
${ }^{49}$ APFK, sygn. 6, Punkta na Macieja Ziomka, passim, rps.

50 APFK, sygn. 6, Inwentarz Młyna Górnego w Bieńczycach, gdzie Maciey Ziomek mieszka, spisany Roku 1796, passim, rps.

${ }^{51}$ APFK, sygn. 6, Punkta na Macieja Ziomka, k. 1r, rps.

52 APFK, sygn. 6, Świadectwo od Gromady Bieńczyckiey jako Maciey Gospodarz Młyna Górnego nie chciał reperować Izbicy w 1796, passim, rps.

53 Izbica 'element konstrukcyjny zabezpieczający młyn przed uderzeniami fal, a także płynącymi drzewami i krami’. https://sjp.pwn.pl/doroszewski/izbica;5435426.html, [dostęp: 02.12.2020].

$54 \mathrm{Jaz}$ 'element konstrukcyjny służący spiętrzeniu wody w rzece'. https://sjp.pwn.pl/ doroszewski/jaz;5435968.html, [dostęp: 02.12.2020].

55 APFK, sygn. 6, Reparacya Górnego Młyna w Bieńczycach [...] w czerwcu, lipcu, sierpniu roku 1796, passim, rps.

${ }^{56}$ APFK, sygn. 6, Punkta na Macieja Ziomka, k. 1r, rps.
} 
Również koła wodne, kamienie młyńskie i ponur ${ }^{57}$ opisane zostały w całości jako $\mathrm{w}$ złym stanie ${ }^{58}$. W konkluzji odnotowano zaś, że „[...] całkiem się to powtarza, że nie masz takiego mieysca, gdzie by nie

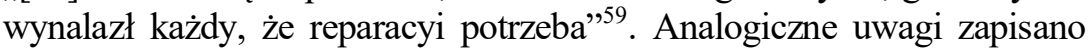
o stanie zabudowań gospodarczych, $\mathrm{w}$ tym piekarni, stajni i stodoły ${ }^{60}$.

Ówczesny dzierżawca wsi, Józef Kałużyński, spisał ponadto kilka świadectw dokumentujących wydarzenia w Bieńczycach w 1796 r. W źródłach tych odnotowano, że sam dzierżawca wielokrotnie upominał młynarza, aby ten pilnował jazu i izbicy, a także by przeprowadził konieczne naprawy ${ }^{61}$. Młynarz jednakże, jak pisze Kałużyński, wolał pilnować karczmy, a przez swoje niedbalstwo i skąpstwo zaniedbywał młyn ${ }^{62}$. „W nocy spał dobrze y spokojnie, nie myśląc o wodzie" $^{63}$. Wreszcie wskutek większych opadów w 1796 r. ,[...] woda przypadłszy nagła, doszczętu Izbicę zruynowała, groble stargała y jazu dobrze nadruynowała" ${ }^{44}$.

Jeszcze tego samego roku za staraniem Kałużyńskiego przeprowadzone zostały niezbędne reparacje. Postawa młynarza nie uległa jednak zmianie. Również w latach 1797-1798 przeprowadzono drobne prace naprawcze bez udziału młynarza, jednak w 1798 r. woda ponownie dokonała spustoszenia i najpierw przy izbicy zrobiła dół na głębokość 3 łokci, aby wreszcie rzeczoną izbicę doszczętnie zniszczyć $^{65}$. Przyczyniło się to do napływu nowych, licznych skarg na Macieja Ziomka do proboszcza parafii pw. św. Floriana, w których wskazywano, że naprawianie i pilnowanie młyna stanowić miały jego powinność. Zgodnie wskazywano, że ten ,[...] śmiał się z tego wszystkiego, a na przestrogi tak Dominium iako i Proboszcza lub od gromady same szyderstwa zuchwale czynił" ${ }^{\prime 6}$. Wójt bieńczycki pouczać

\footnotetext{
57 Ponur 'część obudowania koryta płynącej wody położona powyżej piętrzącej wodę śluzy’. https://sjp.pwn.pl/doroszewski/ponur;5477205.html, [dostęp: 02.12.2020].

58 APFK, sygn. 6, Rewizya Młyna Górnego w 1796 roku, passim, rps.

59 Tamże, k. 2r.

60 Tamże.

${ }^{61}$ APFK, sygn. 6, Oświadczenie dzierżawcy wsi Kałużyńskiego z 1797 r., passim, rps.

62 Tamże, k. 1r.

63 Tamże.

64 Tamże.

${ }^{65}$ APFK, sygn. 6, O spustoszeniu Młyna Górnego w Bińczycach i oddaleniu od niego Macieja Ziomka do Cyrkułu Krakowskiego, k. 2r, rps.

66 Tamże, k. 3v.
} 
miał go nadto: „[...] sobie człowieku sam na złe czynisz, pamiętaj co za koniec twój będzie"67. Wskutek tej niedbałości również w 1799 r. młyn pozostawał zepsuty ${ }^{68}$.

Wreszcie ostatnim z wysuwanych zarzutów przeciwko Maciejowi Ziomkowi, a najczęściej podejmowanym, była kwestia kontraktu, jaki młynarz zawarł z ówczesnym proboszczem, ks. Krząnowskim. W źródłach systematycznie pojawia się informacja, że ,[...] kontrakt jego miał być emfiteutyczny"69, tzn., że młynarz dzierżawił grunt od proboszcza z prawem czerpania z niego wszelkich korzyści, a także z możliwością wznoszenia na nim nowych budynków, nie nabywając przy tym prawa własności gruntu. Maciej Ziomek jednakże nigdy nie otrzymał oryginału kontraktu i legitymować miał się wyłącznie jego kopią. Kwestia ta stanowiła więc główny argument w próbach podważenia ważności zawartej przezeń umowy przy dodatkowym wykazywaniu, że rzeczonego kontraktu i tak nie przestrzega ${ }^{70}$. Wśród dokumentów przechowywanych $\mathrm{w}$ archiwum parafii pw. św. Floriana w Krakowie zachowany jest zarówno oryginał kontraktu z 1788 r. ${ }^{71}$, jak i jego niepodpisana kopia z 1791 r. $^{72}$, z których wynika, że Maciej Ziomek otrzymał młyn w dzierżawę na „czworo dożywocia”, tj. pozostawać miał w posiadaniu jego rodziny do śmierci jego oraz jego małżonki, a także ich dwójki dzieci: Jędrzeja i Apollonii ${ }^{73}$. Wśród najważniejszych ustaleń kontraktu zapisane zostały: czynsz w wysokości 180 złp płacony corocznie w dniu św. Marcina Biskupa, a także inne daniny i podatki względem dworu i gromady ${ }^{74}$. Ustalono wreszcie,

${ }^{67}$ APFK, sygn. 6, Świadectwo od Woyta Bieńczyckiego na spustoszenie Młyna Górnego w 1796 r., k. 1r, rps.

${ }^{68}$ W 1799 r. prowadzone były prace naprawcze przy młynie w pobliskiej Mogile. Na mocy porozumienia część gruntu należącego do Bieńczyc oddana została Mogile, aby możliwe było wydrążenie nowego kanału doprowadzającego wodę z Dłubni. APFK, sygn. 7, Zamiana Gruntu na Jaz między Mogiłą i Binczycami, passim, rps.

69 APFK, sygn. 6, O spustoszeniu Młyna Górnego w Bieńczycach i oddaleniu od niego Macieja Ziomka do Cyrkuły Krakowskiego, k. 1r, rps.

${ }^{70}$ Tamże.

71 APFK, sygn. 28, Kontrakt na Młyn Górny w Bieńczycach Ziomkom dany 1788 20 października, passim, rps.

72 APFK, sygn. 82, Kontrakt na Młyn Górny w Bieńczycach Ziomkom dany 1791

1 marca, passim, rps.

73 Tamże, k. 1r.

${ }^{74}$ Tamże, k. 1r-1v. 
że po zakończeniu dzierżawy młyn powrócić ma do dyspozycji dworu bieńczyckiego w lepszym stanie. „Słowem poczciwie, wiernie, nienagannie Ziomkowie sprawować się maią" - stanowił kontrakt ${ }^{75}$.

W omawianym czasie w Młynie Dolnym mieszkał i pracował Bonawentura Jastrzębski wraz ze swoją żoną Katarzyną ${ }^{76}$. Wiosną 1794 r. przeprowadzone zostały prace remontowe, gdyż młyn był w bardzo złym stanie ${ }^{77}$. Niemalże natychmiast po dokonaniu napraw został ponownie zrujnowany. Wina za to obarczony został Maciej Ziomek ${ }^{78}$. $\mathrm{W}$ jedynym dokumencie zawierającym opis tej sytuacji, w relacji administratora bieńczyckiego F. Dziukiewicza, wskazano, że w 1795 r. mocą dekretu sądowego nakazano Ziomkowi poniesienie kosztów naprawy Dolnego Młyna jako wynagrodzenie za uczynioną szkodę. Jednakże zdaniem Dziukiewicza to nie Maciej Ziomek ponosił winę za powstałe zniszczenia, lecz Katarzyna Jastrzębska - żona młynarza z Dolnego Młyna. Po zakończonej reparacji ponuru zarówno wójt, jak i Ziomek przestrzegali Jastrzębskich, że ziemia świeżo usypana przy ponurze podatna będzie na skruszenie przez wodę, dlatego nie należy jej doń wpuszczać. Jastrzębska jednak nie bacząc na te przestrogi pozostawiła ponur otwarty na noc, co doprowadziło do uszkodzenia młyna ${ }^{79}$.

Przytoczona powyżej sprawa stała się zarzewiem konfliktu trwającego pomiędzy młynarzami również w kolejnych latach. Po spustoszeniu Młyna Górnego, Jastrzębski zeznawał przeciwko Ziomkom, a jego świadectwo wzmiankowane jest systematycznie we wszystkich spisach dokumentów procesowych. W 1796 r. w jednym z pism skar-

\footnotetext{
75 Tamże, k. 1v.

76 Bonawentura Jastrzębski objął w posiadanie rzeczony młyn na mocy kontraktu zawartego przez swojego ojca, Tomasza Jastrzębskiego. Podczas buntu chłopów w 1791 r. rodzina Jastrzębskich wysunęła żądanie anulowania kontraktu dożywotniego i podpisania w jego miejsce wieczystego. W złożonej przez siebie skardze wskazywali, że w latach 1762-1787 ks. Krząnowski podnosił czynsz nałożony na Młyn Dolny, mimo że wskutek wylania Dłubni ten został uszkodzony. Spór jednakże rozstrzygnięty został polubownie w 1788 r., dlatego też sędzia delegowany przez Szkołę Główną Koronną odmówił wydania drugiego wyroku w tej samej sprawie, pomimo ponowienia skargi młynarza. AUJ, sygn. 1/28, Dekret Sądu Delegacyjnego Szkoły Głowney Koronney z dn. 14 III 1792, k. 1r-2r, rps.

${ }^{77}$ APFK, sygn. 82, Decretum contra Jastrzębski Molitor in Binczyce 1794 r., k. 1r-1v, rps. 78 APFK, sygn. 6, Świadectwo administratora F. Dziukiewicza z dn. 1 X 1795 r., k. $1 \mathrm{r}, \mathrm{rps}$.

$79 \mathrm{Z}$ powodu braku stosownych dokumentów rozstrzygnięcie tej sprawy pozostaje niemożliwe. Tamże.
} 
żył się on nadto, że w chwili gdy woda zaczęła niszczyć izbicę Dolnego Młyna natychmiast zwrócił się z prośbą do Macieja Ziomka o zamknięcie jazu Górnego Młyna. „Ten jednak żadnym sposobem nie chciał pozwolić, zaczym przez Jego upór Izbicę doszczętu zruynowała woda na tysiączną szkodę" ${ }^{\text {"80 }}$. Szczegółowy opis Młyna Dolnego sporządzono podczas rewizji zabudowań dworskich w Bieńczycach w 1797 roku $^{81}$. Odnotowano wówczas, że drewno, z którego był on zbudowany było całe przegniłe, elementy mocowań drzwi i okien stare, brak było również podłogi w większości budynku. Oszacowano w dokumencie tym również, że koszt naprawy młyna wynieść miał $2500 \mathrm{złp}^{82}$. Musiał więc pozostawać w znacznie gorszym stanie niż Młyn Górny, którego koszt naprawy w źródle tym określono na $500 \mathrm{zlp}^{83}$.

Mimo licznych skarg, świadectw, dekretów, napomnień i wszystkich innych działań zmierzających do odebrania Maciejowi Ziomkowi młyna, cel ten nie został osiągnięty. Nie udało się również obarczyć go kosztami naprawy. Cały spór zakończyła dopiero śmierć młynarza w 1801 r., a do uregulowania kosztów naprawy Młyna Górnego w wysokości 1144,21 złr zmuszono pozostałą po nim wdowę Apollonię ${ }^{84}$. Uregulowana przez nią suma stanowiła zaledwie część poniesionych kosztów. Po powrocie młyna do dyspozycji dworskiej został on ponownie wyremontowany nakładem ówczesnego proboszcza, ks. Franciszka Kolendowicza. Jednakże oczekiwano, że dług ten zostanie przez następnych młynarzy spłacony ${ }^{85}$.

\section{Spór o Młyn Górny pomiędzy Tomaszem Kiereckim a gromadą bieńczycką i proboszczami świętofloriańskimi (1803-1838)}

Nie wiadomo kiedy dokładnie w Młynie Górnym pojawił się nowy młynarz. Brak jest również informacji, aby zgodnie z przywilejem

80 APFK, sygn. 6, Swiadectwo Jastrzębskich na Macieja Ziomka dla spustoszenia Izbicy, k. 1r, rps.

81 APFK, sygn. 7, Rewizya Dworskich wszelkich Pobudowli w Wsi Binczycach uczyniona Roku 1797, passim, rps.

82 Tamże.

83 Tamże.

${ }^{84}$ APFK, sygn. 6, Oryginał Expensy po śp. Macieiu Ziomku dnia 12 grudnia 1801, passim, rps.

85 APFK, sygn. 6, Proiekt do zakupieństwa młyna ręką ks. Kolendowicza pisany, k. $1 \mathrm{r}-1 \mathrm{v}$, rps. 
danym rodzinie Ziomków przez ks. Krząnowskiego odziedziczony został on przez dzieci Macieja Ziomka. Jednakże rodzina ta z pewnością nie opuściła młyna, a Apollonia Ziomkowa wyszła za mąż po raz trzeci. Wskutek czego nowym młynarzem został Jan Danek ${ }^{86}$. Również i z nim współpraca nie układała się ani po myśli proboszcza, ani gromady. We wrześniu 1804 r. ks. Kolendowicz wystosował obszerne pismo do Józefa Nideckiego, ówczesnego dzierżawcy wsi, z upoważnieniem, aby wypowiedział kontrakt Dankowi i zajął młyn najpóźniej do dnia św. Marcina (tj. 11 listopada), po którym to dniu młyn miał zostać przeznaczony na licytację ,[...] z przyczyn dobrze całey wsi

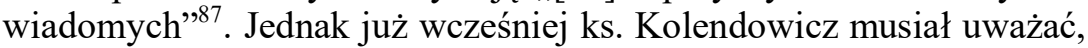
że młynarz zajmuje młyn bezprawnie, skoro w sporządzonym w maju 1804 r. inwentarzu probostwa nie ma wzmianki o Danku, a jedynie zapis, że Ziomkowi „,[...] iuż wyszła Possessya y młyn odebrany iest na Dominium" " 8 . W rzeczonym piśmie do Nideckiego ks. Kolendowicz wyliczył trzy zarzuty względem nowego młynarza. Po pierwsze wykazywał, że „cały rok bezprawnie siedzi we Młynie” nie przestrzegając przy tym kontraktu ani nie dbając o budynki ${ }^{89}$. Jako drugi zarzut zwrócił uwagę na fakt, iż Danek nie chciał spłacać długu, co miało być jego obowiązkiem w myśl umowy zawartej przez jego poprzedni$\mathrm{ka}^{90}$. Wreszcie odmówił on również sporządzenia nowego kontraktu, nie uprawiał też gruntu do młyna przynależącego ${ }^{91}$.

Brak jest informacji, czy planowana na 1804 r. licytacja doszła do skutku, bowiem kolejna wzmianka o losach Młyna Górnego pochodzi dopiero z 1807 r., kiedy to ks. Franciszek Kolendowicz przygotował projekt zakupieństwa młyna ${ }^{92}$. Mocą tego dokumentu wraz ze wszystkimi przyległymi zabudowaniami przekazany miał on zostać „,...] uczciwym Tomaszowi Kiereckiemu y Reginie dobrze rekommendo-

\footnotetext{
86 APFK, sygn. 6, Pismo w sprawie wypowiedzenia umowy Dankowi Młynarzowi z dn. 20 IX 1804 r., k. 1r, rps.

87 Tamże.

88 APFK, sygn. 101, Inwentarz Probostwa S. Floryana na Kleparzu w Krakowie w maju 1804 sporządzony, rps.

89 APFK, sygn. 6, Pismo w sprawie wypowiedzenia umowy Dankowi Młynarzowi $\mathrm{z}$ dn. 20 IX 1804 r., k. 1r, rps.

90 Tamże, k. 1v.

91 Tamże, k. 1v-2r.

${ }^{92}$ APFK, sygn. 6 ,
} 
wanym"93. Zaakcentowana w źródle dobra opinia, jaką cieszył się Tomasz Kierecki okazała się być krótkotrwała, zachowane jest bowiem pismo z dnia 26 maja 1808 r. stwierdzające, że młynarz ,[...] wystawił się na widok nayniegodziwszego człowieka we wsi" "' "Źródło to ponadto poświadcza, iż wspomniany projekt umowy z $1807 \mathrm{r}$. nie wszedł w życie, gdyż Kierecki nie uiścił opłaty i w związku z jego licznymi ,[...] zuchwalstwami y nieposłusznym postępowaniu sobie z zwierzchnością własną" Młyn Górny nie został mu sprzedany ${ }^{95}$.

Licytację przeprowadzono z pewnością 22 września 1808 r. W jej wyniku za kwotę 2088 złp prawo do dzierżawy młyna nabył Jakób Komolski ${ }^{96}$. Brak jest jednakże jakichkolwiek wzmianek, aby podpisano z nim kontrakt. Z pewnością umowę zawrzeć musiano z Tomaszem Kiereckim, skoro w 1813 r. ponownie odnotowano obszerną listę jego przewinień. Rzeczone zarzuty nie różniły się znacznie od tych, które stawiano wcześniej Maciejowi Ziomkowi, czy też Janowi Dankowi. Podobnie jak poprzedni młynarze Danek nie dbał o młyn ani nie uprawiał gruntu. Ponadto nie spłacał długu określonego wówczas na 379,15 złp, nie wykonywał również zadań zleconych przez dwór z powodu „ustawicznego pijaństwa"97. Odnotowano także, że ,[...] z ludźmi, którzy mielaią u niego często się kłuci i bije a Młyny przeto się psuią i pustoszeią" "98. Mimo tego Tomasz Kierecki nie został usunięty i pracował jako młynarz bieńczycki przez następne lata. Zapewne chcąc zabezpieczyć się przed napotkaniem takich samych trudności jak w końcu XVIII w., ks. Kolendowicz sprzedał Kiereckiemu młyn za 3000 złr, jednak nie zawarł z nim kontraktu $^{99}$. W zapisanym 16 marca 1825 r. „wywodzie słownym” sam młynarz wspomniał o tym, że przywilej miał ,[...] przyrzeczony przez tegoż ś.p. Xiędza Kolendowicza na owczas Proboszcza, że go [...] wyrobi i oddać postara się" ${ }^{100}$, do czego jednak nigdy nie doszło.

\footnotetext{
93 APFK, sygn. 6, Proiekt do zakupieństwa młyna ręką JWX Kolendowicza pisany, k. $1 \mathrm{r}$, rps.

94 APFK, sygn. 6, Pismo z dn. 26 V 1808 r., k. 1r, rps.

95 Tamże.

${ }^{96}$ APFK, sygn. 6, Licytacja Młyna Górnego w Bińczycach 1808, k. 1r, rps.

${ }^{97}$ APFK, sygn. 6, Pakta przeciw Tomaszowi Kiereckiemu młynarzowi, k. 1r, rps.

98 Tamże.

99 ANK, Wolne Miasto Kraków (29/200), sygn. WMK IX-26, Wywód słowny Tomasza Kiereckiego z dn. 16 III 1825 r., k. 1r-1v, rps.

100 Tamże.
} 
W 1813 r. nadal notowano w źródłach większy czynsz spoczywający na Młynie Górnym, tj. 370 złr, podczas gdy z Młyna Dolnego, w którym w 1813 r. pracował już syn Bonawentury Jastrzębskiego - Stanisław Jastrzębski ${ }^{101}$, pobierać miano $200 \mathrm{ztr}^{102}$. W rzeczywistości jednak Tomasz Kierecki opłacał jedynie część czynszu - 270 złr $^{103}$. Pomimo kierowanych pod jego adresem ponagleń nie udało się wyegzekwować całej należności ${ }^{104}$.

Dnia 25 marca 1818 r. Młyn Dolny został przez Jastrzębskich sprzedany Wawrzyńcowi Basiowi ${ }^{105}$, który przeprowadził w nim znaczne prace remontowe ${ }^{106}$. Jednak Młyn Górny pozostawał w złym stanie. W 1822 r. ówczesny wójt gminy Mogiła złożył zawiadomienie do Wydziału Spraw Wewnętrznych i Policji Wolnego Miasta Krakowa $\mathrm{o}$, ,...] upadaiącym młynie w Bieńczycach posiadanym przez Tomasza Kiereckiego"107. Uwagę Wydziału zwrócił przede wszystkim bardzo zły stan obiektu i groźba jego rychłego zawalenia, a także fakt, iż zniszczona izbica zagrażała drugiemu młynowi ${ }^{108}$. Powróciła wobec tego kwestia usunięcia z funkcji Tomasza Kiereckiego, gdyż ten ,[...] nałogowi piiaństwa zupełnie oddany [...] straciwszy przez piiaństwo cały swój maiątek, w żaden sposób gdyby nawet chciał ieszcze na szkode przedsięwziąść [sic!] środki nie poprawi stanu upadaiącego młyna"109. Podobnie jak w przypadku Macieja Ziomka, nigdy nie doszło do

\footnotetext{
101 ANK, Wolne Miasto Kraków (29/200), sygn. WMK IX-26, Wywód słowny Wawrzyńca Basia z dn. 22 III 1825 r., k. 1r-1v, rps.

102 ANK, Wolne Miasto Kraków (29/200), sygn. WMK IX-26, Wyciąg z Inwentarza Wsi Bieńczyc w Roku 1813 sporządzonego, k. 2v-3r, rps.

103 ANK, Wolne Miasto Kraków (29/200), sygn. WMK IX-26, Wywód słowny Tomasza Kiereckiego z dn. 16 III 1825 r., k. 2r, rps.

104 Tamże.

105 Zgodnie z zawartym kontraktem, Stanisław Jastrzębski wraz z żoną Katarzyną po sprzedaży młyna mieli w nim nadal mieszkać aż do śmierci. ANK, Wolne Miasto Kraków (29/200), sygn. WMK IX-26, Wywód słowny Wawrzyńca Basia z dn. 22 III 1825 r., k. 2r, rps.; ANK, Wolne Miasto Kraków (29/200), sygn. WMK IX-26, Pismo z dn. 27 X 1824 r., k. 1r, rps.

106 Tamże.

107 ANK, Wolne Miasto Kraków (29/200), sygn. WMK IX-26, List Feliksa Radwańskiego z dn. 26 IV 1822 r., passim, rps.

108 Tamże, k. 1r.

109 Tamże, k. 1r-2v.
} 
jego zwolnienia ${ }^{110}$. Sprawę rozstrzygnięto dopiero $\mathrm{w} 1838 \mathrm{r}$., kiedy to już po śmierci młynarza zawarto umowę o zrzeczenie się praw do młyna z Apollonią, wdową po Macieju Ziomku, wskutek czego legalny kontrakt o dzierżawę młyna przypadł Michałowi Koczwie ${ }^{111}$.

\section{Zakończenie}

Mimo zachowania się niezwykle licznych i obszernych źródeł poświadczających dzieje młynów bieńczyckich, zgromadzone informacje pozostają niekompletne. $\mathrm{O}$ wydarzeniach niektórych lat brak jest jakichkolwiek wzmianek, $\mathrm{z}$ tego też powodu niektóre $\mathrm{z}$ wątków pozostać muszą nierozstrzygnięte.

Nasuwa się na zakończenie niniejszych rozważań pytanie o przyczynę wywołania konfliktu o Młyn Górny w Bieńczycach. Koniec XVIII w. był czasem, w którym nagromadzeniu uległy rozliczne i przytoczone w niniejszym artykule trudności wynikające z nierozsądnej gospodarki prowadzonej przez dzierżawców. Spór o młyn zdaje się w tej perspektywie jawić jako możliwy wynik upadku autorytetu ponad 90-letniego wówczas ks. Antoniego Krząnowskiego, którego zaawansowany wiek ośmielił gromadę bieńczycką do wszczęcia buntu. Zwrócić uwagę należy ponadto, że powstałe w tymże czasie zadłużenie ciążące na młynie, było z perspektywy osiemnastowiecznego chłopa niezwykle trudne do spłacenia. Sam bardzo zły stan młyna był zresztą wynikiem wieloletnich zaniedbań, które uległy nagromadzeniu w końcu XVIII w. Uwagę należy zwrócić również na problem nadużywania alkoholu i propinacji, a więc aspektów powszechnie występujących i mających destrukcyjny wpływ na polską wieś. Opisany konflikt w znacznej mierze przyczynił się do zaniedbania młyna i w konsekwencji do jego zniszczenia w XIX w. Pomimo bogatej dokumentacji brak jest jakichkolwiek wzmianek w źródłach o tym, aby spór ten wpłynął negatywnie na finanse, jakimi dysponował proboszcz krakowskiej parafii pw. św. Floriana.

\footnotetext{
110 Archiwum Kurii Metropolitalnej w Krakowie, sygn. IPK A 4, Inwentarz Koscioła Sgo Floryana przez Komissyę Cywilno Duchowną w Roku 1828m spisany, s. 91, rps. 111 ANK, Wolne Miasto Kraków (29/200), sygn. WMK IX-26, Wywód słowny Michała Koczwy z dn. 27 IV 1838 r., k. 1r-2v, rps.
} 


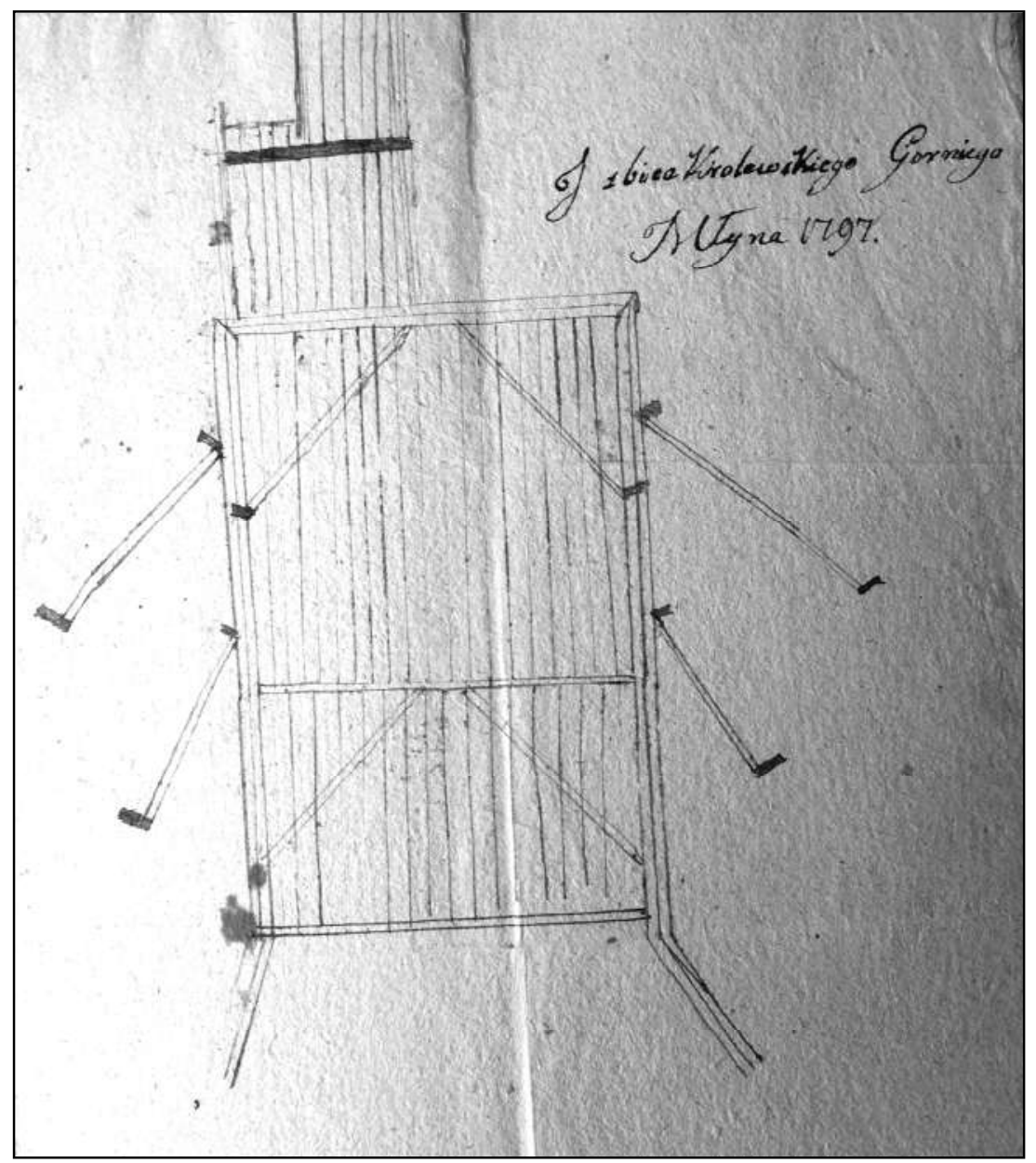

Il. 1. Izbica Młyna Górnego w Bieńczycach 


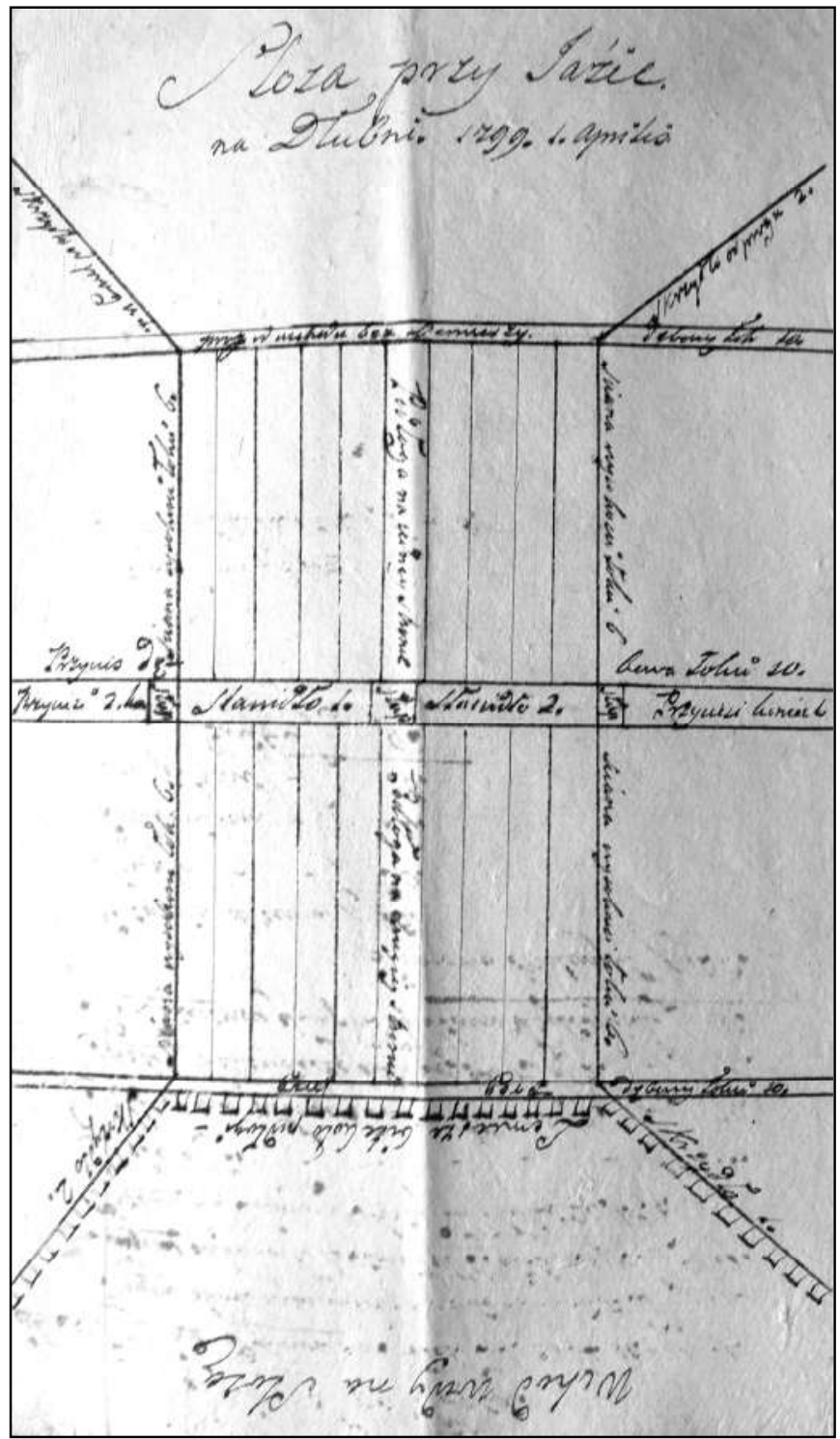

Il. 2. Śluza przy jazie na Dłubni 


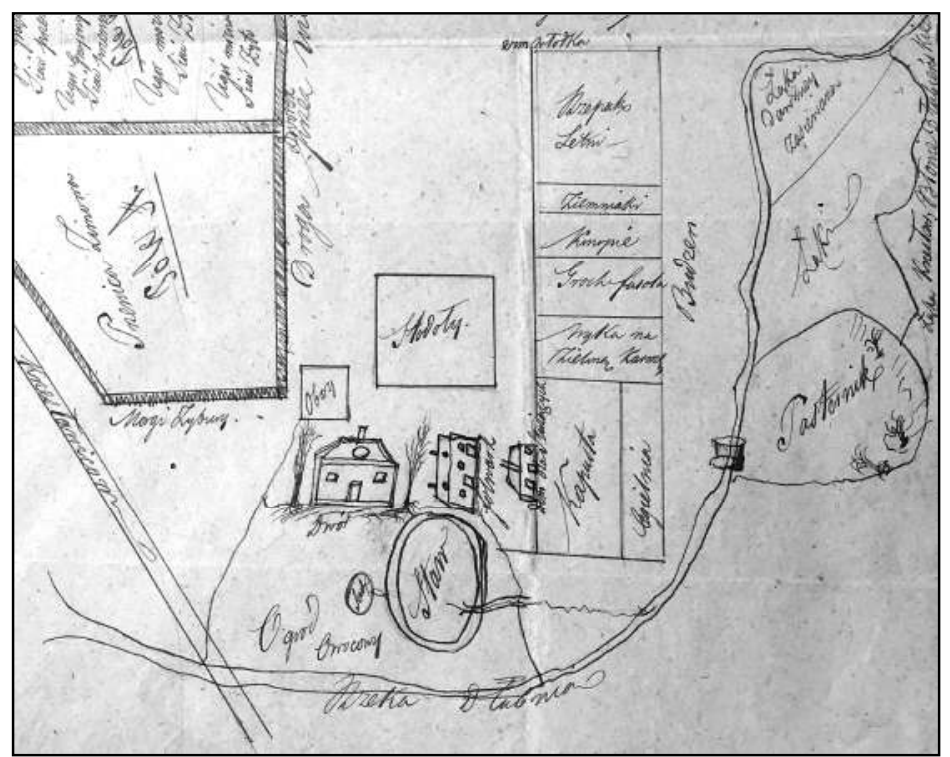

Il. 3. Zabudowania folwarczne w Bieńczycach w 1849 r.

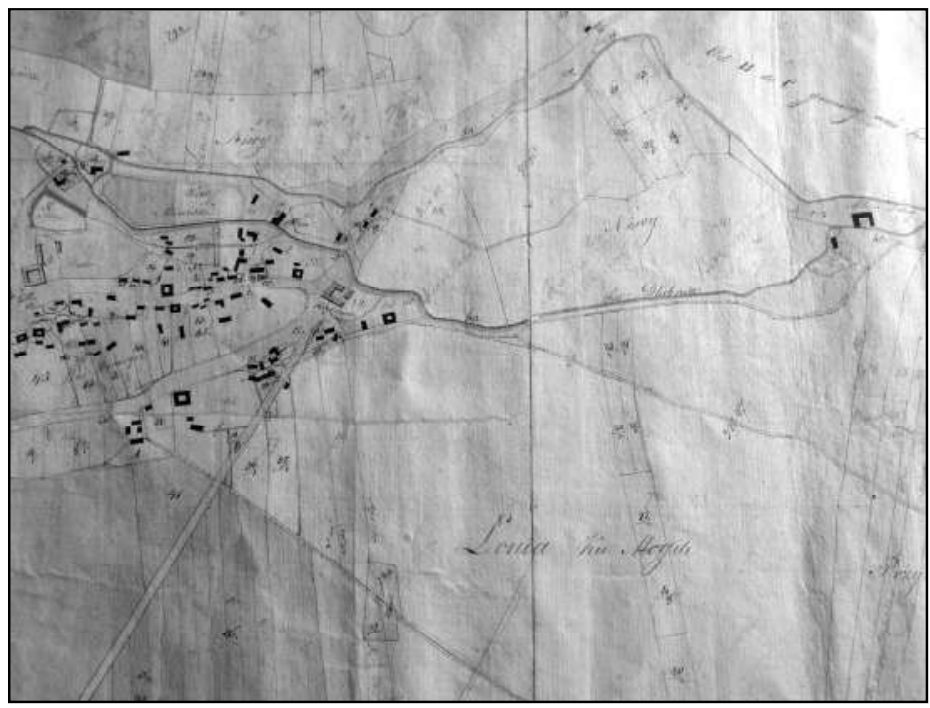

Il. 4. Fragment mapy Bieńczyc z 1823 r. dokumentujący położenie młynów 


\section{BIBLIOGRAFIA}

\section{Źródla rękopiśmienne}

\section{Archiwum parafii pw. św. Floriana w Krakowie}

- sygn. 6, Dokumenty dotyczące wsi Bieńczyce.

- sygn. 7, Dokumenty dotyczące wsi Bieńczyce.

- sygn. 28, Libertatis inquilinorum in fundi praepositurali habitantium.

- sygn. 36, Zbiór różnych dokumentów.

- sygn. 60 , Kontrakty.

- sygn. 63, Włościanie bieńczyccy.

- sygn. 71, Dokumenty erekcyjne.

- sygn. 79, Inwentarze kościoła św. Floriana z 1804 r.

- sygn. 80, Dokumenty dotyczące wsi Bieńczyce.

- sygn. 82, Młyny w Bieńczycach.

- sygn. 101, Inwentarz probostwa św. Floriana w maju 1804 sporządzony.

Archiwum Narodowe w Krakowie

- Wolne Miasto Kraków (29/200), sygn. WMK IX-26, Bieńczyce.

- Wolne Miasto Kraków (29/200), sygn. WMK Okr. 2, Mappa wsi Bińczyc do funduszów probostwa ś. Floryana należącey 1823.

- Wolne Miasto Kraków (29/200), sygn. WMK Okr. 3, Inwentarz pomiaru wsi Bieńczyce.

- Wolne Miasto Kraków (29/200), sygn. WMK Okr. 3, Mappa Bieńczyc 1823.

\section{Archiwum Uniwersytetu Jagiellońskiego w Krakowie}

- sygn. 172, Regestrum Ecclesiae Collegiatae s. Floriani.

- sygn. 1/27, Dekret Sądu Delegacyjnego Szkoły Głowney Koronney z dn. 14 III $1792 \mathrm{r}$.

- sygn. 1/28, Dekret Sądu Delegacyjnego Szkoły Głowney Koronney z dn. 14 III $1792 \mathrm{r}$.

\section{Biblioteka Jagiellońska w Krakowie}

- sygn. rkp. dypl. 330, Kontrakt na Młyn Górny.

\section{Archiwum Kurii Metropolitalnej w Krakowie}

- sygn. IPK A 4, Inwentarz Kosciola Sgo Floryana przez Komissyę Cywilno Duchowną w Roku 1828m spisany.

\section{Źródła drukowane}

Długosz J., Liber beneficiorum Dioecesis Cracoviensis, t. 1, opr. A. Przeździecki, Kraków 1863.

Limanowski B., Hugo Kołtątaj, Warszawa 1920.

Pamiątka 700 letniej rocznicy założenia kościoła i kolegiaty św. Floryana przy Krakowie na Kleparzu, Poznań 1883. 
Śniadecki J., Żywot literacki Hugona Kotłąaja z opisaniem stanu Akademii Krakowskiej w jakim się znajdowata przed rokiem 1780, opr. H. Barycz, Wrocław 1951.

\section{Źródla internetowe}

Izbica, https://sjp.pwn.pl/doroszewski/izbica;5435426.html Jaz, https://sjp.pwn.pl/doroszewski/jaz;5435968.html

Ponur, https://sjp.pwn.pl/doroszewski/ponur;5477205.html

\section{Opracowania}

Dembińska M., Przetwórstwo zbożowe w Polsce średniowiecznej (X-XIV wiek), Wrocław 1973.

Kramarz H., Mlynarze i mtynarstwo zbożowe w Galicji (Z problematyki uprzemystawiania rzemiosta chłopskiego), [w:] Polska i Polacy w XIX-XX wieku. Studia ofiarowane Profesorowi Mariuszowi Kulczykowskiemu w 70. rocznicę Jego urodzin, red. K. Ślusarczyk, Kraków 2002, s. 295-317.

Kuś J., Kołtątaj i Kapituła Krakowska, „Rocznik Krakowski” 1977, t. 48, s. 19-56.

Podwińska Z., Rozmieszczenie wodnych młynów zbożowych w Małopolsce wXV wieku, „Kwartalnik Historii Kultury Materialnej” 1971, nr 1, s. 373-402.

Szczepaniak J., Duchowieństwo świętofloriańskie $w$ XVIII $i$ XIX wieku, [w:] Studia z dziejów kościoła św. Floriana w Krakowie, red. Z. Kliś, Kraków 2007, s. 35-106.

\section{Wykaz ilustracji}

Il. 1. Izbica Młyna Górnego w Bieńczycach. Źródło: APFK, sygn. 6, Izbica Krolewskiego Gornego Młyna 1797, rps.

Il. 2. Śluza przy jazie na Dłubni. Źródło: APFK, sygn. 6, Sloza przy Jazie na Dłubni 1799, rps.

Il. 3. Zabudowania folwarczne w Bieńczycach w 1849 r. Źródło: APFK, sygn. 80, Widok pol i zasiewów Dworskich Bieńczyckich dnia 16 lipca 1849 roku, rps.

Il. 4. Fragment mapy Bieńczyc z 1823 r. dokumentujący położenie młynów. Źródło: ANK, Wolne Miasto Kraków (29/200), sygn. WMK Okr. 2, Mappa wsi Bińczyc do funduszów probostwa ś. Floryana należącey 1823, rps. 